\title{
miR-6745-TIMP1 axis inhibits cell growth and metastasis in gastric
}

\section{cancer}

\author{
Hui Liu ${ }^{1,{ }^{*}}$, Yuan Xiang ${ }^{1,2, *}$, Qi-Bei Zong ${ }^{1,}{ }^{*}$, Xiao-Yu Zhang ${ }^{1}$, Zhi-Wen Wang $^{3}$, Shi-Qiang Fang ${ }^{2}$, \\ Tong-Cun Zhang ${ }^{1}$, Xing-Hua Liao ${ }^{1}$
}

\author{
${ }^{1}$ Institute of Biology and Medicine, College of Life and Health Sciences, Wuhan University of Science and \\ Technology, Hubei 430081, P.R. China \\ ${ }^{2}$ Department of Medical Laboratory, Central Hospital of Wuhan, Tongji Medical College, Huazhong University of \\ Science and Technology, Hubei 430014, P.R. China \\ ${ }^{3}$ Yueyang Key Laboratory of Chronic Noncommunicable Diseases, Yueyang Vocational and Technical College, \\ Hunan 414000, P.R. China \\ *Equal contribution
}

\begin{abstract}
Correspondence to: Tong-Cun Zhang, Xing-Hua Liao; email: zhangtongcun@wust.edu.cn, xinghualiao@wust.edu.cn Keywords: TIMP1, miR-6745, oncogenesis, Wnt/ $\beta$-catenin pathway, gastric cancer Abbreviations: IOD: integrated optical density; UTR: untranslated region; GC: gastric cancer Received: August 6, 2021

Accepted: October 27, 2021

Published: November 14, 2021
\end{abstract}

Copyright: (C) 2021 Liu et al. This is an open access article distributed under the terms of the Creative Commons Attribution License (CC BY 3.0), which permits unrestricted use, distribution, and reproduction in any medium, provided the original author and source are credited.

\section{ABSTRACT}

Tissue inhibitor matrix metalloproteinase 1 (TIMP1) has been reported to act as a tumor oncogene in colon cancer. However, little is known about the biological role of TIMP1 in gastric cancer. In this study, we found that the expression of TIMP1 in GC tissues was upregulated compared with the normal gastric tissues. TIMP1 was confirmed as a direct target of miR-6745 and silencing TIMP1 mimicked the effects of miR-6745 in GC cells. Further mechanism studies have shown that miR-6745 inhibits the Wnt/ $\beta$-catenin pathway by targeting TIMP1, thereby inhibiting cell proliferation, migration and invasion. In addition, through the analysis of GC tissues, a negative correlation between miR-6745 and TIMP1 was found in 42 GC tissues. Our findings indicate that the miR-6745-TIMP1 axis regulates Wnt/ßcatenin signaling and participates in GC tumorigenesis and provide a potential therapeutic target for preventing GC progression.

\section{INTRODUCTION}

Gastric cancer (GC) is a frequently occurring malignant cancer $[1,2]$. According to statistics from the World Health Organization, there are approximately 1 million new cases of GC patients every year, and GC has become the third leading cause of cancer deaths worldwide $[2,3]$. Although an increasing number of GC diagnosis and treatment strategies have been developed in recent years, the prognosis of patients is still very poor $[4,5]$. Thus, it is important to elucidate the molecular mechanism of the occurrence and development of GC.

MicroRNA is an endogenous small non-coding RNA that can regulate protein expression levels [6, 7]. It has been reported that miRNAs play important biological functions in various types of human cancers, including oncogenes or tumor suppressor genes [8, 9]. Exploring the molecular mechanisms that miRNA regulates the occurrence and development of cancer will help the treatment and diagnosis of tumors.

Tissue inhibitor matrix metalloproteinase 1 (TIMP1) is one of the tissue inhibitor members of the metalloproteinase family [10]. TIMP1 regulates the balance of matrix remodeling during the degradation of extracellular matrix by inhibiting the proteolytic activity of matrix metalloproteinases (MMPs) [10, 11]. Studies have shown that TIMPs also perform important biological functions in cell proliferation and metastasis [10, 12-14]. 
In clinical studies, the high expression of TIMP-1 in the serum of patients with various tumors is often associated with poor prognosis [15-17]. However, the molecular mechanism of TIMP1 in GC remain to be elucidated.

Our research is to explore the biological function of miR6745 in the development of GC. miR-6745 regulates the expression of TIMP1 to inhibit cell growth and reduce the ability of metastasis in vitro and in vivo. In addition, we proved the role of miR-6745/TIMP1/Wnt/ $\beta$-catenin signaling in the development of GC.

\section{RESULTS}

\section{TIMP1 is upregulated in human gastric cancer}

To investigate whether TIMP1 is upregulated in Gastric Cancer (GC), we first examined TIMP1 expression in 42 cases of GC and 42 adjacent normal gastric tissues. Immunochemistry revealed that, compared with control colon tissues TIMP1 was upregulated in gastric cancer tissues (Figure 1A, 1B). By testing the frozen gastric tissues, we also found that TIMP1 increased in protein
A

A

Adjacent normal gastric tissues
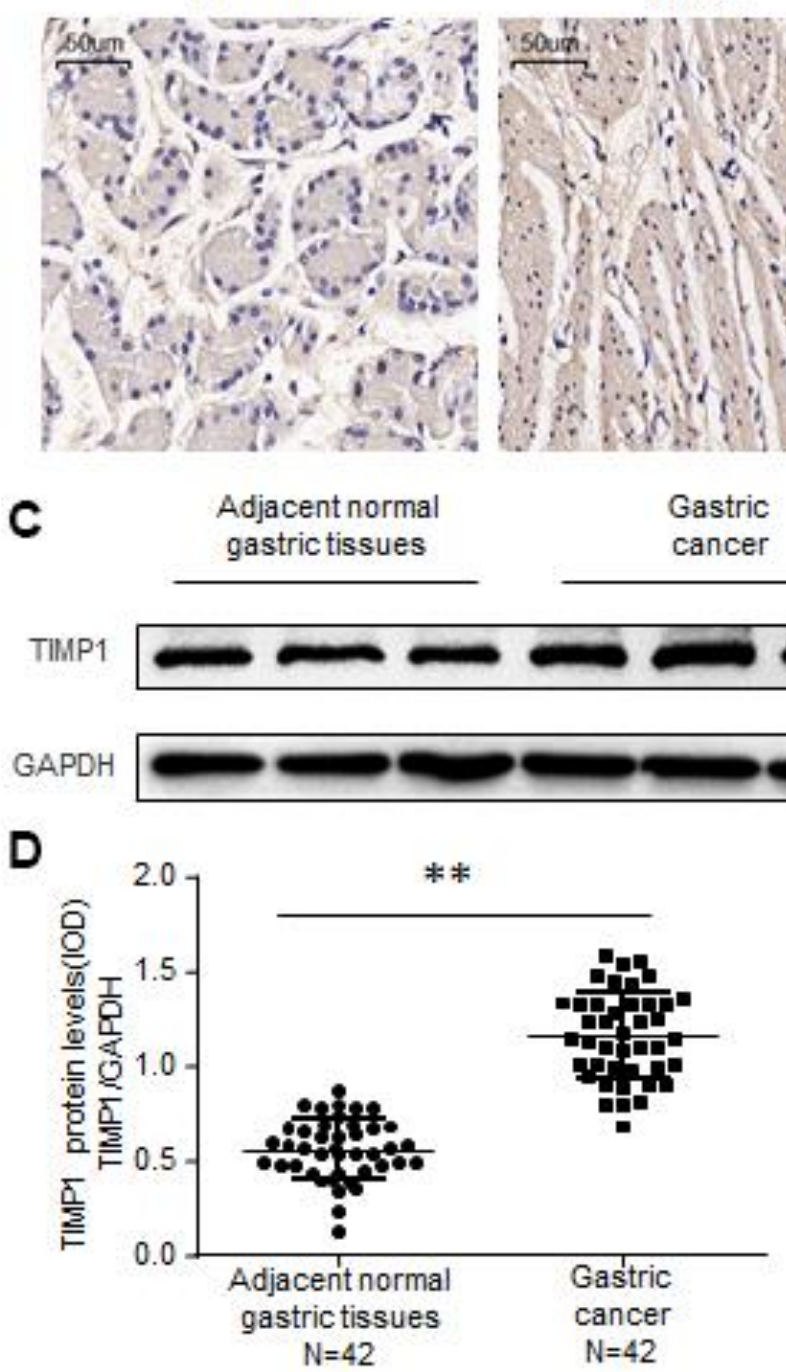
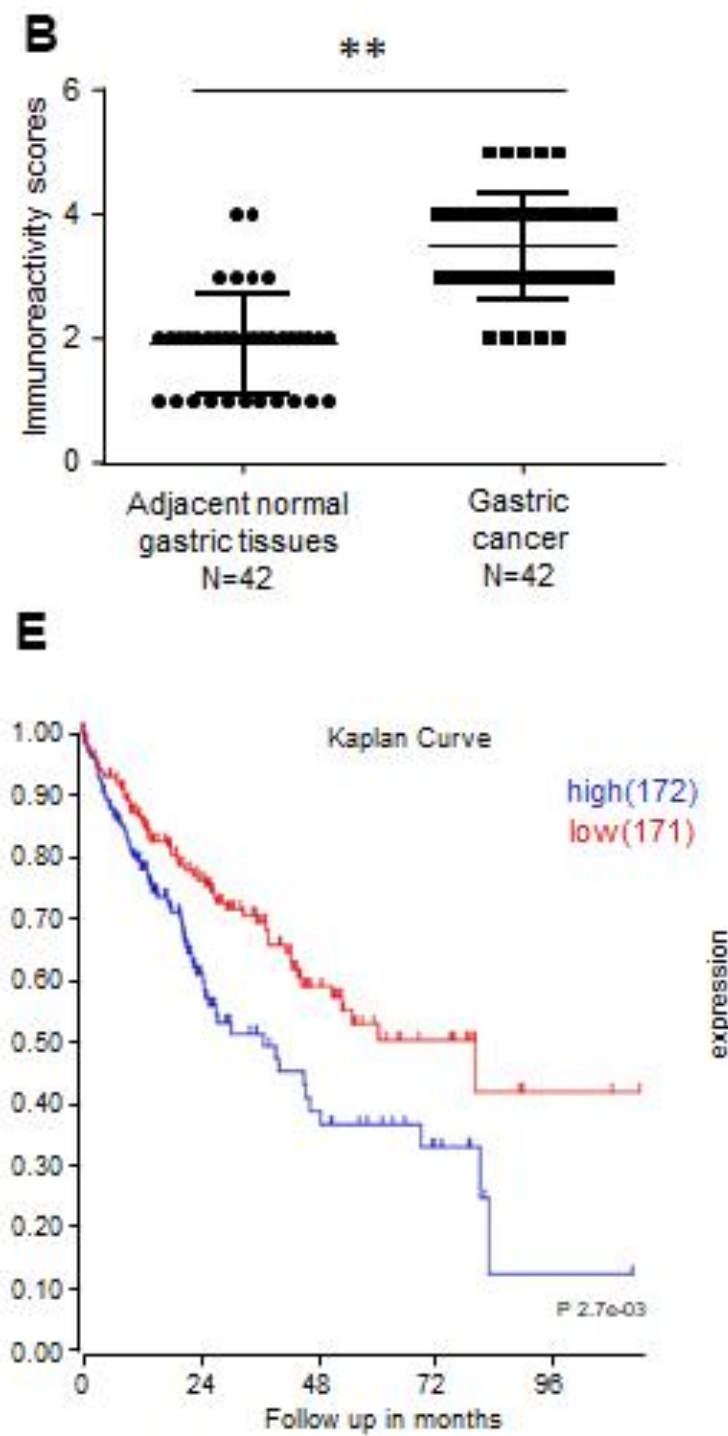

Figure 1. TIMP1 is upregulated in human gastric cancer. (A, B) Immunohistochemistry of TIMP1 expression in 42 gastric carcinoma tissues and 42 adjacent normal gastric tissues. Representative immunohistochemistry images (A) and semi-quantitative evaluation (B) of TIMP1protein expression. (C, D) Analysis of TIMP1 expression in 42 gastric carcinoma tissues and 42 adjacent normal gastric tissues. Representative western blotting images of TIMP1 protein levels in three normal gastric tissues and three gastric carcinoma tissues (C). TIMP1 and GAPDH protein levels were determined via densitometry using ImageJ and are represented as IOD (D). (E) Kaplan-Meier survival analyses of GC patients with high or low TIMP1 expression based on KM plotter database and GSE15459 dataset Data represent the means \pm SEM. $* * \mathrm{P}<0.01$. ns, not significant. 
levels (Figure 1C, 1D). Kaplan-Meier analysis showed that high levels of TIMP1 expression are associated with poor overall survival rates of GC patients. In summary, these findings indicate that TIMP1 expression is upregulated in GC tissues.

\section{TIMP1 promotes GC proliferation, migration and invasion}

To explore the biological function of TIMP1 in the development of GC, GC cells were transduced with siRNAs targeting TIMP1 or TIMP1 overexpression plasmid. Our results showed that, compared with control cells, the proliferation ability was significantly improved in TIMP1 overexpression cells (Figure 2A2C), and inhibited in TIMP1 knockdown cells (Supplementary Figure 1A-1C). Wound healing assay and Transwell showed that, TIMP1 promotes GC migration and invasion (Figure 2D, 2E and Supplementary Figure 1D, 1E). Increased expression of Ki67 indicated that TIMP1 significantly promoted GC cell proliferation (Figure 2F). Subsequently, inhibiting the expression of TIMP1 can also cause a decrease in the expression of Ki67 (Supplementary Figure 2F).

\section{miR-6745 directly binds to the TIMP1 3'-UTR}

Based on bioinformatics analysis, we predicted 5 potential binding miRNAs in TIMP1 3'-UTR (Figure 3A). Real-time RT-PCR results showed that the expression of miRNA-6745 was reduced in GC cells (Figure 3B). Through the detection of 42 cases of GC tissues and 42 adjacent normal gastric tissues, we found that miR-6745 was significantly reduced in GC tissues (Figure 3C). In addition, we found that TIMP1 protein levels were negatively correlated with miR-6745 levels in GC tissues (Figure 3D). To explore whether miR-6745 directly binds to the TIMP1 3'-UTR, dual-luciferase reporter assays were performed (Figure 3E). The results showed that miR-6745 repressed luciferase activity of Wt-TIMP1 3'UTR, but not Mut-TIMP1 3'UTR (Figure $3 \mathrm{~F})$. These findings indicate that miR-6745 directly binds to the TIMP1 3'-UTR.

\section{miR-6745 inhibits GC proliferation, migration and invasion}

TIMP1 promotes the GC process, and TIMP1 is the direct target of miR-6745, we then investigated whether miR6745 have a similar effect on GC tumorigenesis? GC cells were transduced with miR-6745 mimics or miRNA-6745 mimic NC. Firstly, EdU incorporation assay and MTS assay were performed to assess GC cells growth and found that miR-6745 obviously decreased cell proliferation (Figure 4A-4C). Wound-healing and transwell assays were performed in GC cells, as shown in Figure 4D, 4E, the invasive and migratory ability were significantly reduced after transfected with miR-6745 mimics. Immunofluorescence staining also showed that miR-6745 also reduce the expression of KI67 (Figure 4F).

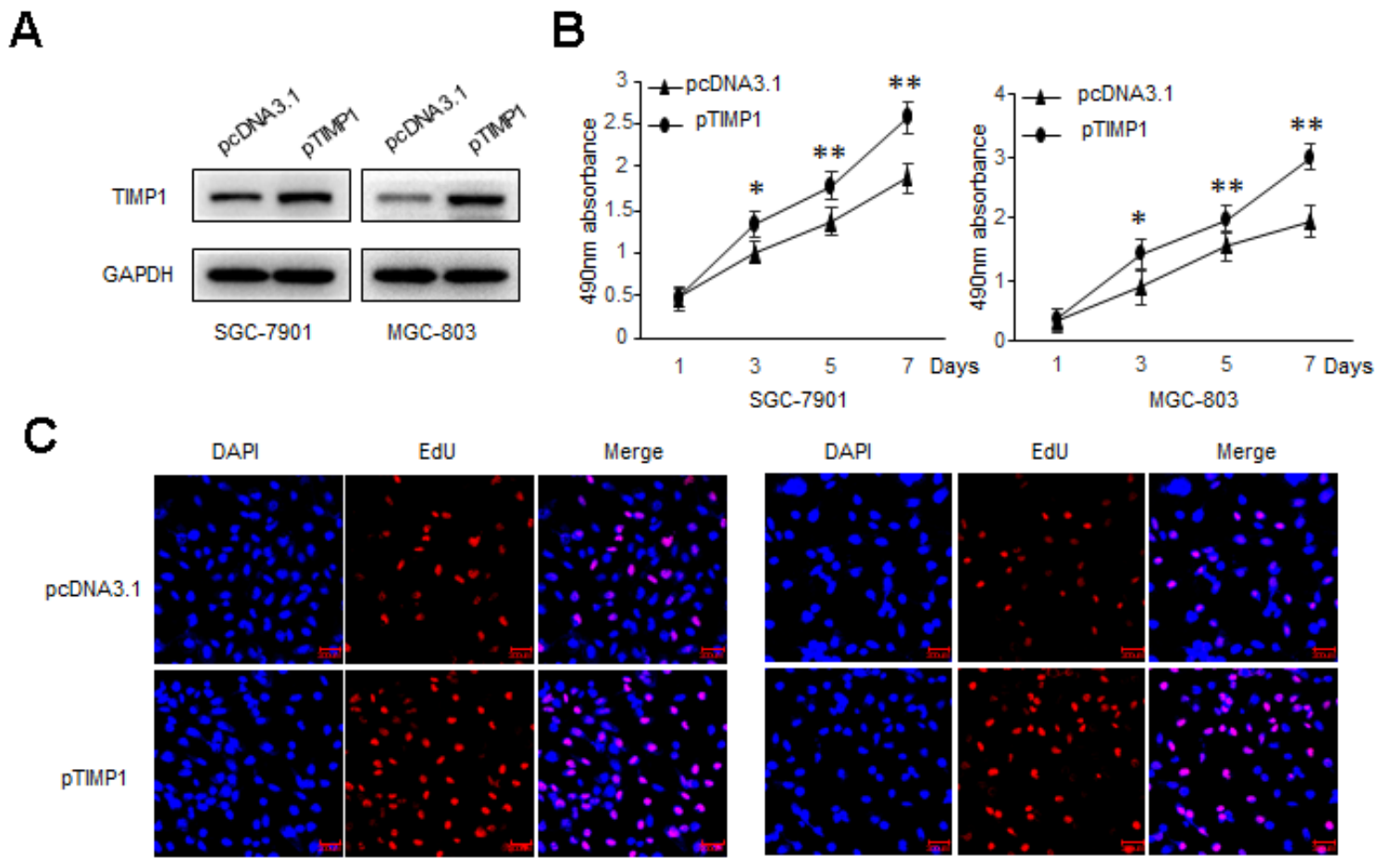


D

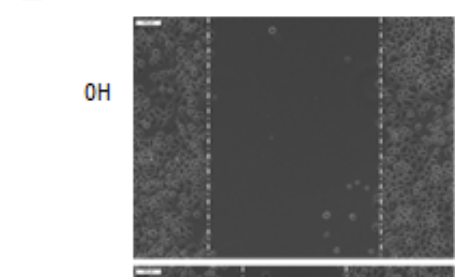

$48 \mathrm{H}$

E

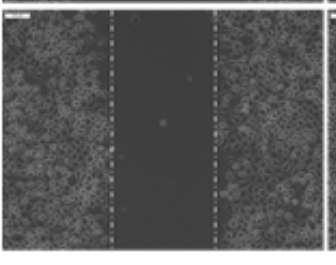

migration

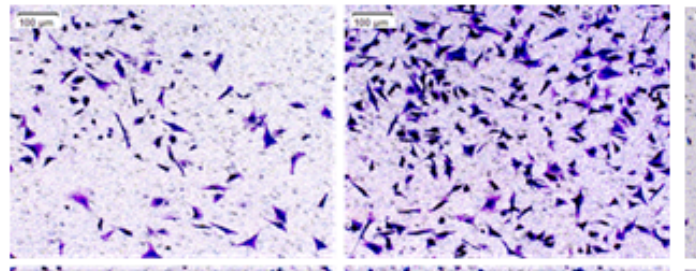

masaben
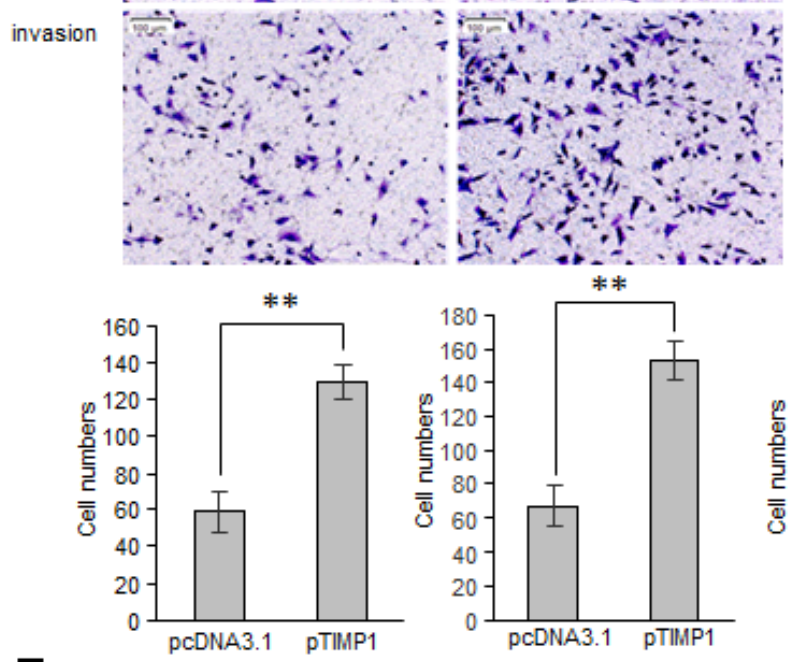

$\mathbf{F}$
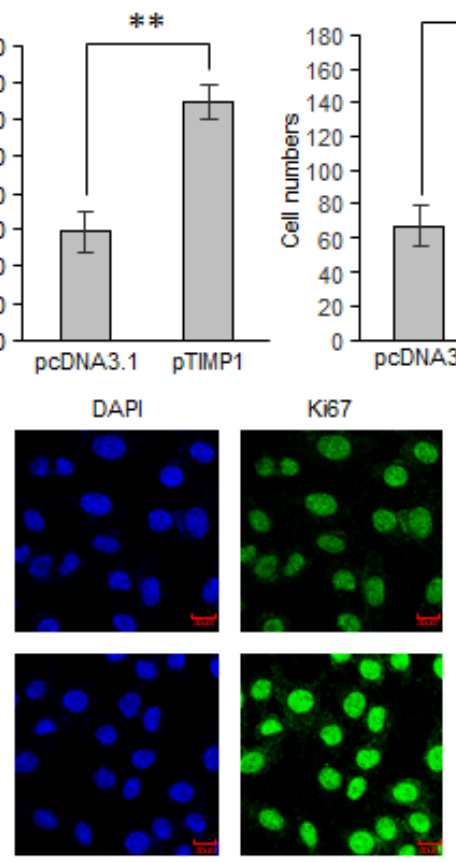

SGC-7901

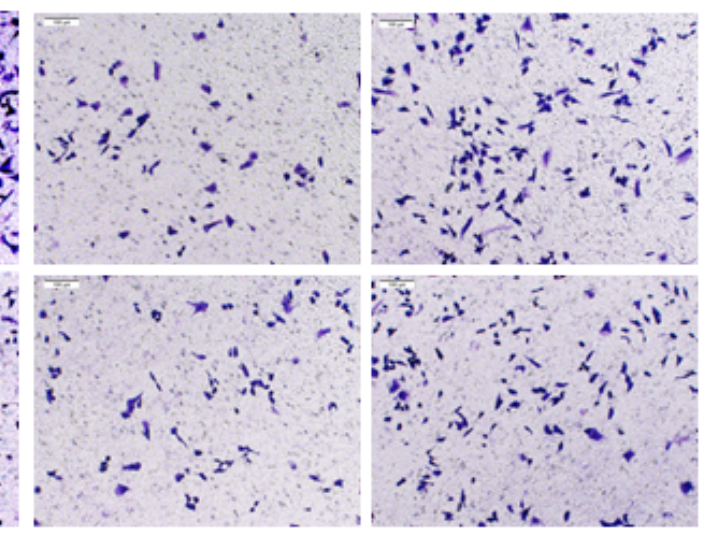

pcDNA3.1

pTIMP1
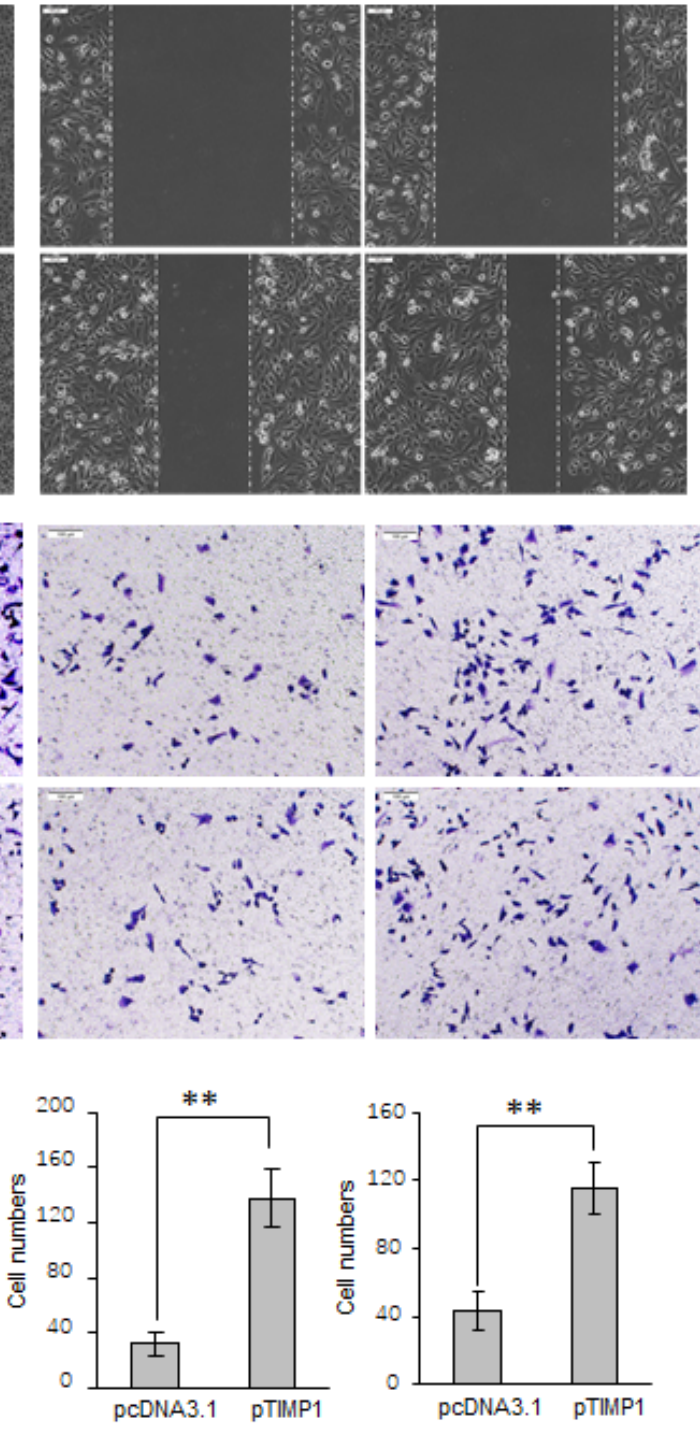

Merge
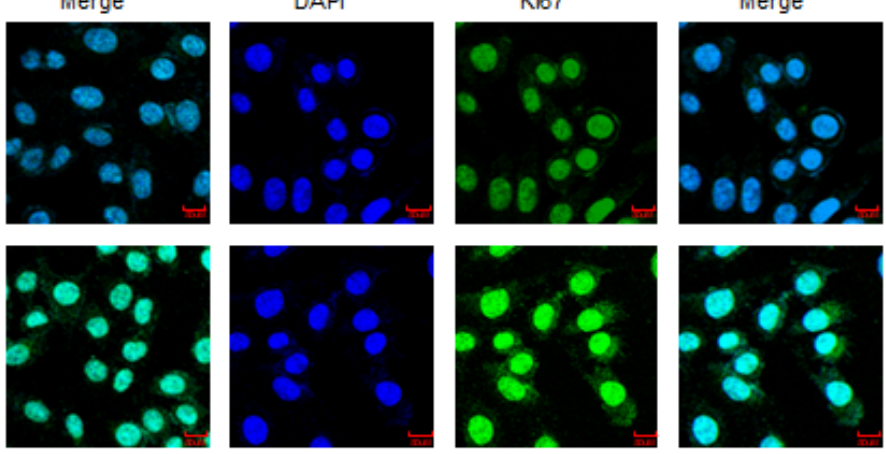

MGC-803

Figure 2. TIMP1 promotes GC proliferation, migration and invasion. SGC-7901 and MGC-803 cells were transduced with TIMP1 expression plasmid (pTIMP1) or pcDNA3.1 as indicated. (A) Levels of TIMP1 were detected by western blot. (B) Cell proliferation was determined at the indicated time points by MTS assay. (C) Effect of TIMP1 on cell proliferative abilities was examined by EdU incorporation assay. (D, E) Cell metastasis was determined by Scratch wound assays (D) or Transwell migration and Matrigel invasion assays (E). (F) The expression levels of the cell proliferation marker Ki67 were detected by immunofluorescence. Data represent the means \pm SEM. $* * P<0.01$. 
A

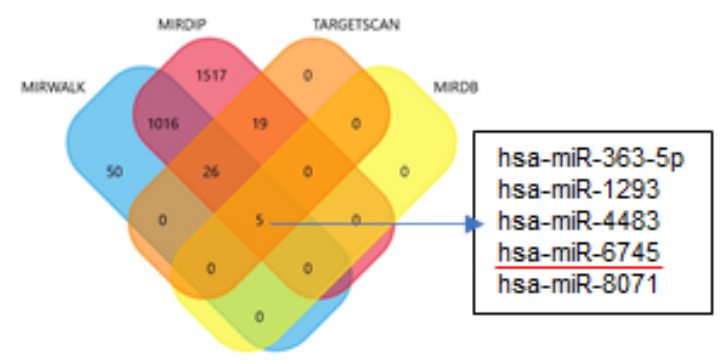

C

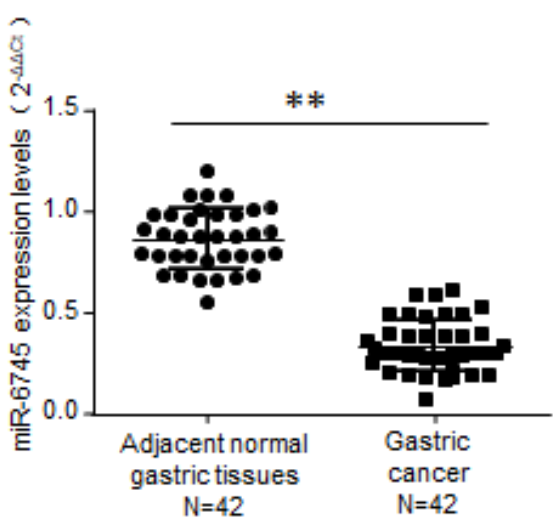

B

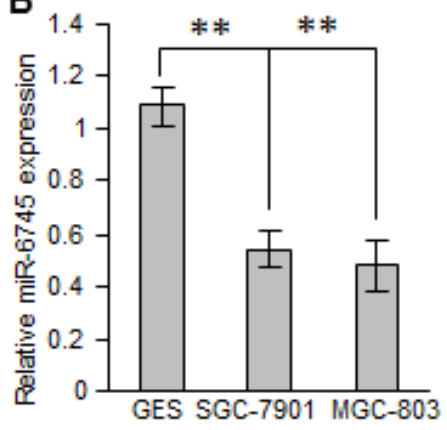

D

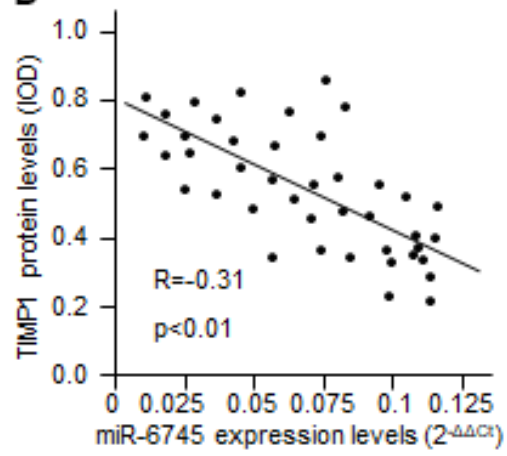

TIMP1 3'UTR-Luci

E

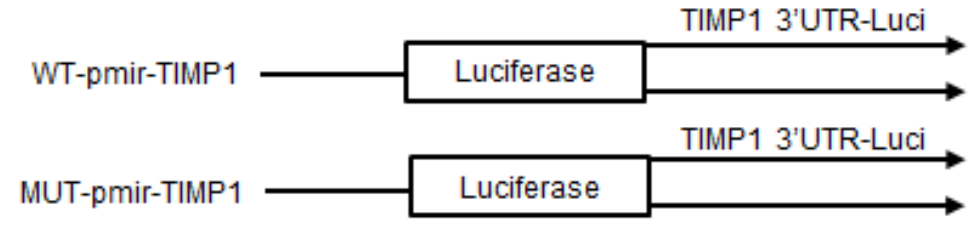

Has-miR-6745-3p

3'- UUGGUCUGGAAGAAGGUGGGU - 5 '

MUT-pmir-TIMP1 3'UTR 5'- AGCCUGCACAGUGGAACUUAU-3'

$\mathbf{F}$

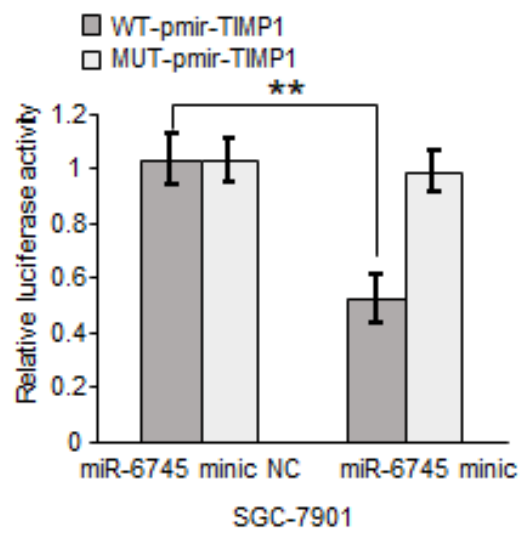

$\square$ WT-pmir-TIMP1

口 MUT-pmir-TIMP1

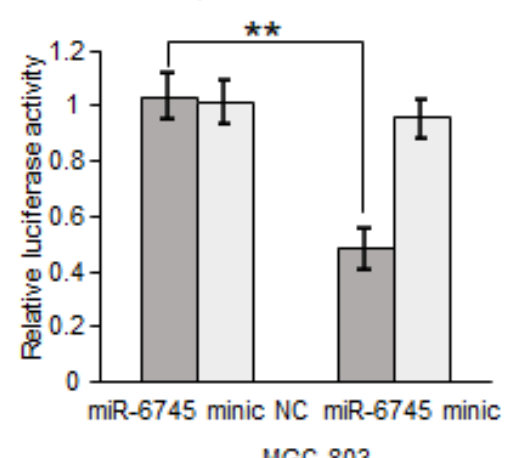

MGC-803

Figure 3. TIMP1 is a direct target of miR-6745. (A) The four-way Venn diagram reveals the numbers of overlapping miRNAs obtained using four publicly available bioinformatics algorithms and the microarray-based TIMP1 signature. (B) Real-time RT-PCR was used to detect the relative expression of miR-6745 in normal gastric cells and gastric cancer cells. (C) Analysis of miR-6745 expression in 42 gastric carcinoma tissues and 42 adjacent normal gastric tissues. (D) Correlation between miR-6745 levels and TIMP1 levels in 42 gastric carcinoma tissues. (E) Nucleotide predicted miR-6745-binding site in the TIMP1 mRNA 3'-UTR. (F) Luciferase activities were measured in SGC-7901 and MGC-803 cells transfected with reporter plasmids containing WT-pmir-TIMP1 or MUT-pmir-TIMP1 together with miR-6745 mimics or miR-6745 mimic NC. Data represent the means \pm SEM. ${ }^{* * P}<0.01$. 


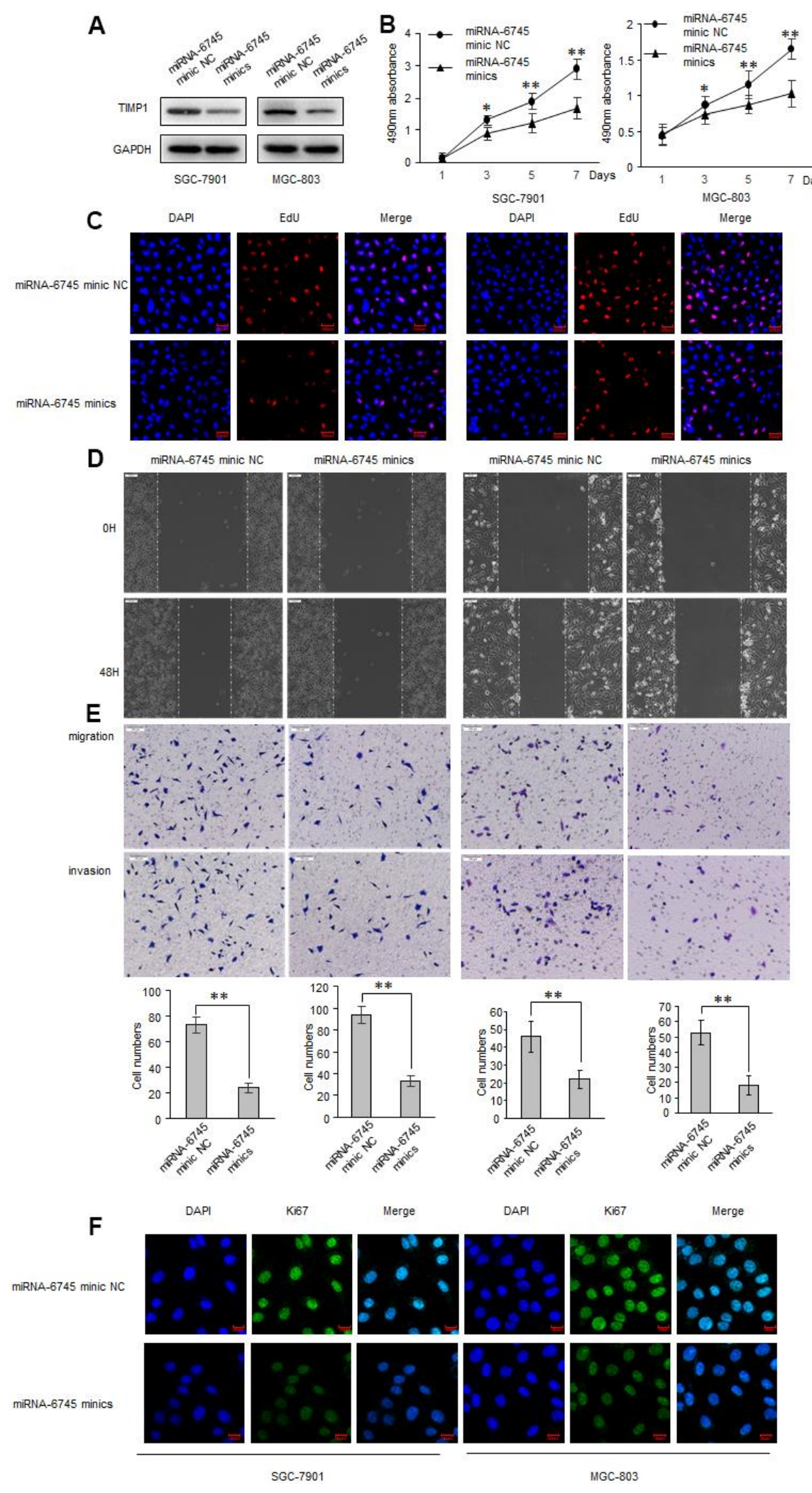

Figure 4. miR-6745 inhibits migratory and invasive ability of GC cells. SGC-7901 and MGC-803 cells were transduced with miRNA6745 mimic NC or miRNA-6745 mimics. (A) Levels of TIMP1 were detected by western blot. (B) MTS assay indicted that miR-6745 mimics inhibited ability of proliferation. (C) Effect of miR-6745 on cell proliferative abilities was examined by EdU incorporation assay. (D) Cell would healing ability was impaired in miRNA-6745 mimics cells. (E) Chamber invasion ability was damaged in miRNA-6745 mimics cells. (F) The expression levels of Ki67 were detected by immunofluorescence. Data represent the means \pm SEM. ${ }^{* * P}<0.01$. 
As expected, the cell proliferation invasive and migratory ability, and the expression of KI67 were significantly elevated when transfected with miR-6745 inhibitors (Supplementary Figure 2).

To explore the biological functions of miR-6745 on GC cell proliferation and metastasis in vivo, we constructed two GC cell lines (Lv-miR-6745-SGC-7901 and Lv-miR6745- MGC-803) that stably overexpresses miR-6745.
Then we injected Lv-miR-6745 or Lv-miR-NC cells subcutaneously into nude mice. All mice were euthanized and stripped of tumor at 28 days after the experiment, the average tumor volumes and weights in Lv-miR-6745 group were smaller than Lv-miR-NC group (Figure 5A, 5B). Immunochemistry showed that that TIMP1 and Ki67 were significantly decreased in the Lv-miR-6745 group (Figure 5C). These results indicate that miR-6745 can inhibit tumorigenesis in vivo.

A
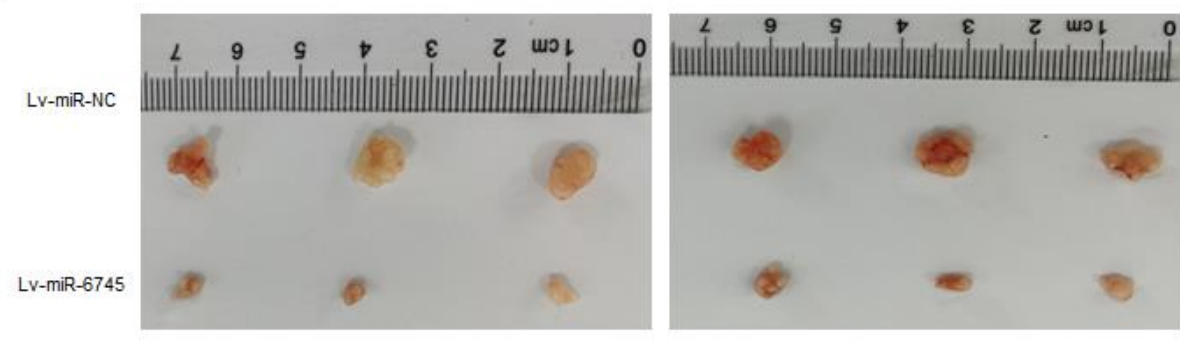

B
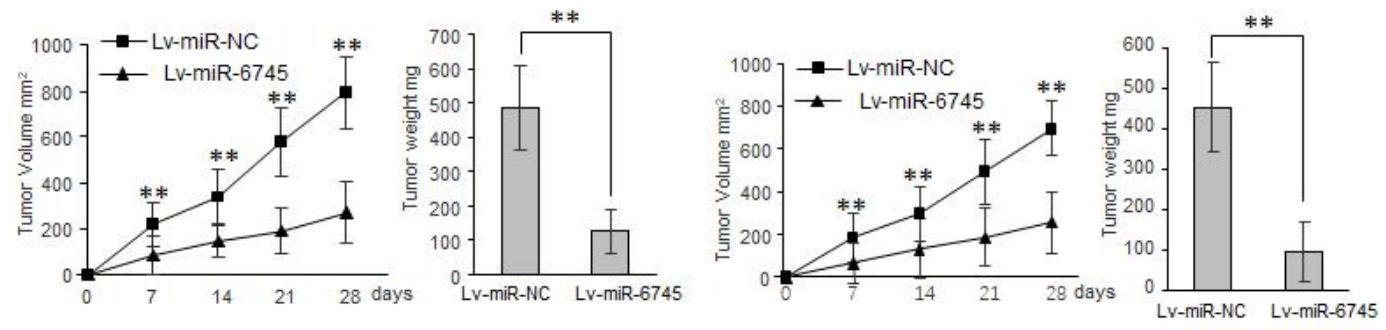

C
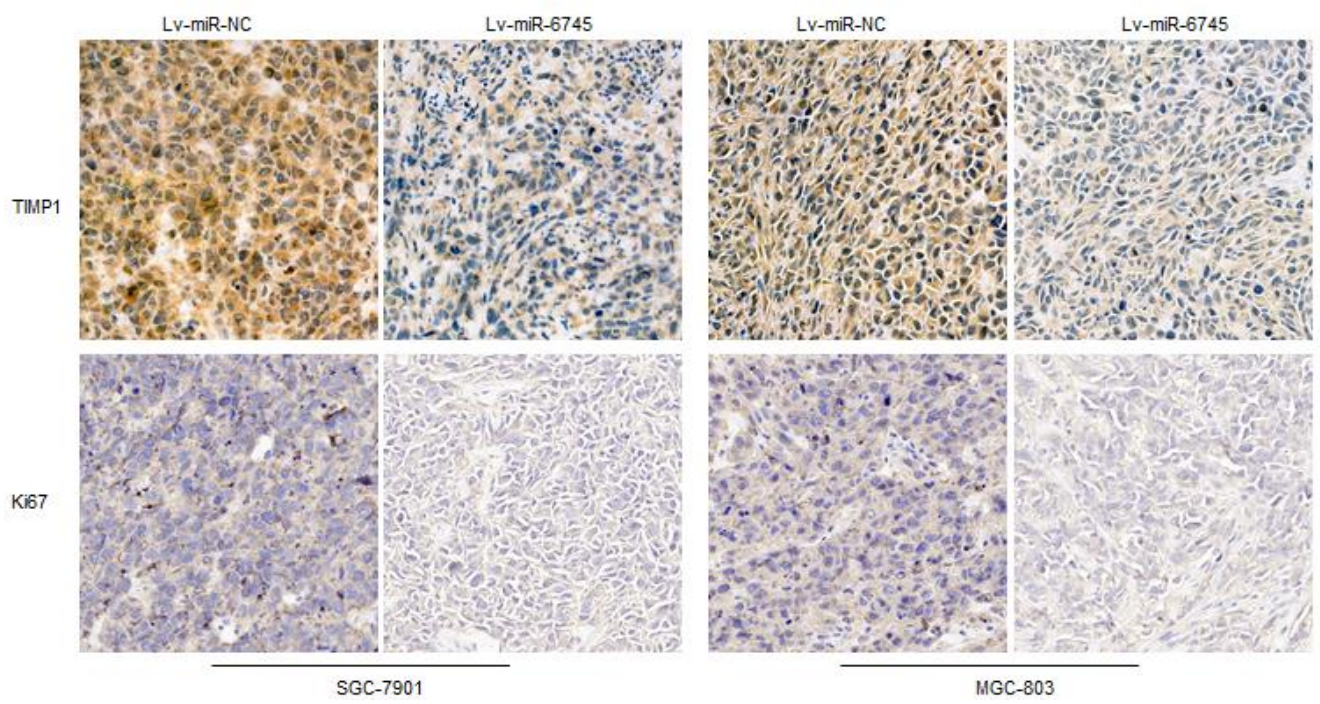

Figure 5. miR-6745 suppresses gastric tumor growth in vivo. Subcutaneous xenografts of GC cells infected with miR-6745 overexpressing lentivirus (Lv-miR-6745) or control lentivirus (Lv-miR-NC). (A) Images of the tumors at autopsy from nude mice are presented. (B) Tumor volumes and average weight of xenografted tumors were measured. (C) Immunohistochemical (IHC) staining of TIMP1 and Ki67 in xenografted tumors from Lv-miR-6745 cells or control cells. Data represent the means \pm SEM. **P $<0.01$. 
miR-6745-TIMP1 axis regulates Wnt/ $\beta$-catenin signaling in GC cells

Overwhelming evidences had demonstrated that $\mathrm{Wnt} / \beta$-catenin signaling play key roles in cancer proliferation, metastasis, and survival [18-20]. We found that TIMP1 can enhance the activity of the $\beta$ catenin reporter gene in GC cells (Figure 6A), while miR-6745 has the opposite effect (Figure 6B). And we found that miR-6745 overexpression or TIMP1

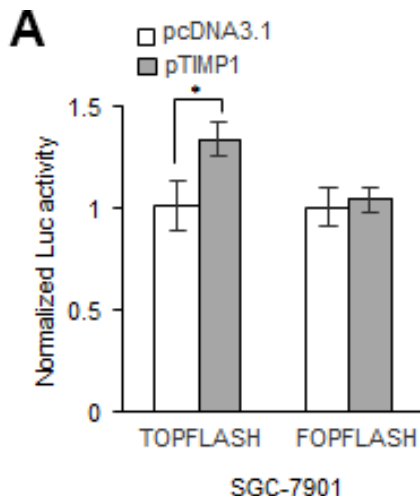

SGC-7901

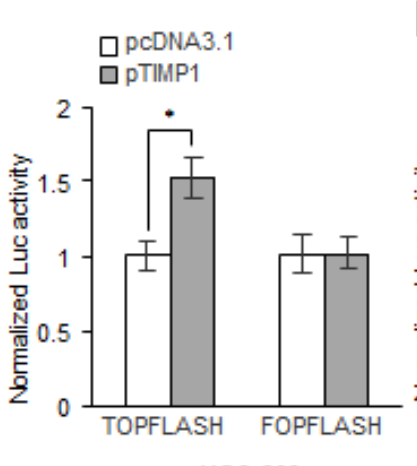

MGC-803

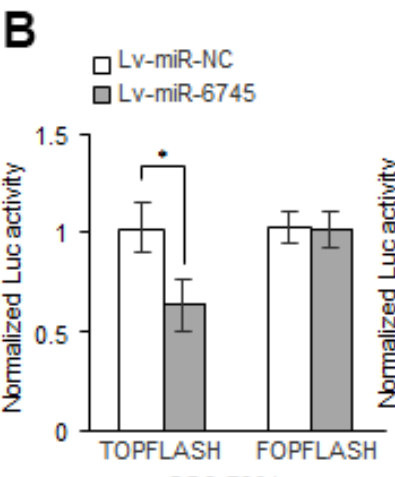

SGC-7901

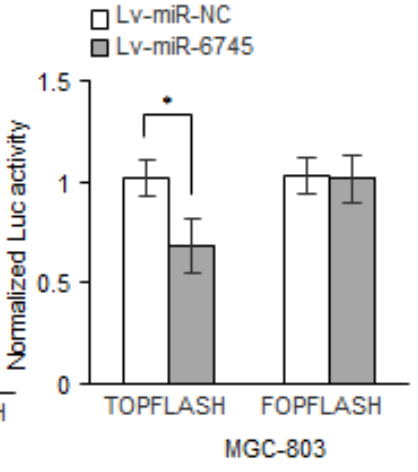

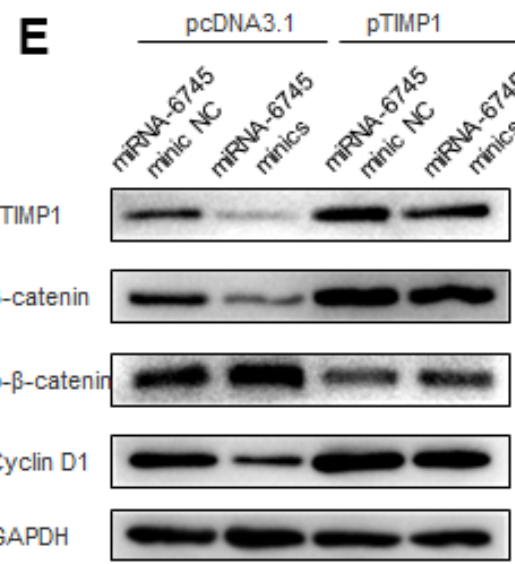

SGC-7901

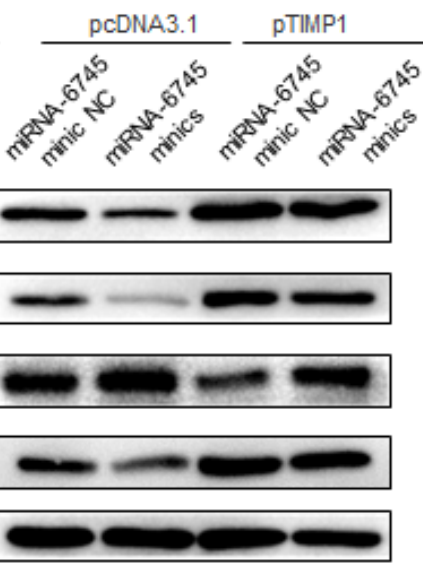

MGC-803
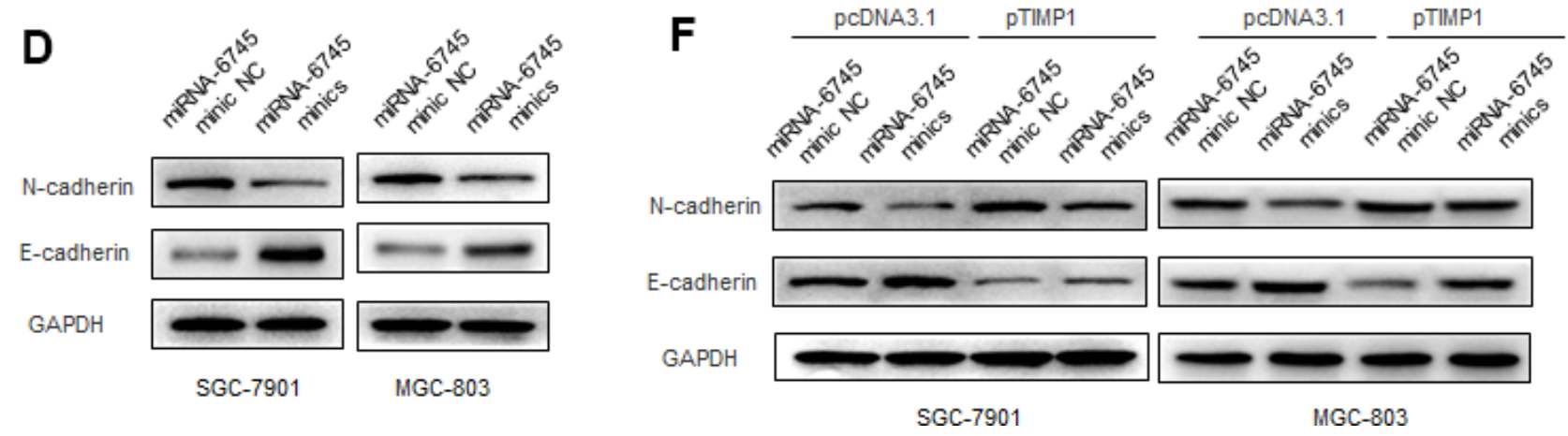

Figure 6. miR-6745-TIMP1 axis regulates Wnt/ $\boldsymbol{\beta}$-catenin signaling in GC cells. (A, B) $\beta$-catenin reporter assay in SGC-7901 and MGC803 cells with TIMP1 overexpression (A) or miR-340 overexpression (B). (C, D) Effects of miR-6745 on protein levels of total $\beta$-catenin, phosphorylated $\beta$-catenin (Ser33/37/Thr41), cyclin D1, E-cadherin and N-cadherin. (E, F) TIMP1 partially restored the levels of total $\beta$-catenin, phosphorylated $\beta$-catenin (Ser33/37/Thr41), cyclin D1, E-cadherin and N-cadherin. Data represent the means \pm SEM. ${ }^{* * P}<0.01$. 
knockdown decreased the expression of total $\beta$-catenin in GC cells, and increased the level of phosphorylated $\beta$-catenin. In addition, we found that the overexpression of miR-6745 inhibited the levels of N-cadherin and cyclin D1 and increased the expression of E-cadherin (Figure 6C, 6D). And we found that TIMP1 can partially restore the expression of phosphorylated $\beta$ catenin, $\beta$-catenin, $\mathrm{N}$-cadherin, E-cadherin and cyclin D1 regulated by miR-6745 (Figure 6E, 6F).

\section{DISCUSSION}

In our study, we found that miR-6745 inhibits the proliferation, migration and invasion of GC cells. We demonstrated that miR-6745 inhibits the Wnt/ $\beta$ catenin signaling pathway by reducing the expression of TIMP1, thereby reducing cell proliferation, migration and invasion in vitro and in vivo. Moreover, the analysis of GC tissues showed that the expression of miR-6745 in GC tissues was low, and it was negatively correlated with TIMP1.

TIMP1, which is the first-discovered natural collagenase inhibitor, has been demonstrated to be related to the occurrence of a variety of cancers $[1,21$, 22]. TIMP-1 has both MMPs-dependent antiproteolytic activity and MMP-independent cell growth activity [23]. Our results show that TIMP1 promotes the occurrence and development of GC, which is consistent with previous reports about TIMP1 as an oncogene in other cancers, including breast cancer [24], colon cancer [10], glioblastoma [25], and non-small cell lung cancer [26].

Wnt pathway is usually divided into classic Wnt signaling pathway (depending on $\beta$-catenin protein) and non-canonical Wnt signaling pathway (not dependent on $\beta$-catenin protein), which is highly conserved signaling pathways in cells $[27,28]$. After the classical Wnt pathway is activated, cytoplasmic $\beta$-catenin escapes the degradation of GSK3 $\beta$, the steady-state concentration increases, and $\beta$-catenin enters the nucleus. It can bind to transcription factors, especially TCF/LEF, to regulate the transcription of target genes [29]. This pathway mainly regulates cell differentiation and proliferation [30, 31]. Abnormally activated Wnt signaling pathway promotes the formation of pancreatic cancer and affects tumor metastasis [32, 33]. Our results show that in GC, overexpression of TIMP1 can activate the Wnt pathway. Abnormal expression of $\beta$-catenin plays an important role in the formation and development of GC [34, 35]. In addition, TIMP1 can also enhance the expression of CyclinD1 [36].

In summary, we found that the downregulation of miR6745 in GC tissues was negatively correlated with the high expression of TIMP1. As summarized in Figure 7, miR-6745 can inhibit the occurrence and development of GC by directly targeting TIMP1 to regulate downstream $\mathrm{Wnt} / \beta$-catenin signaling. Therefore, we provide a new strategy for the prevention, diagnosis and treatment of GC.

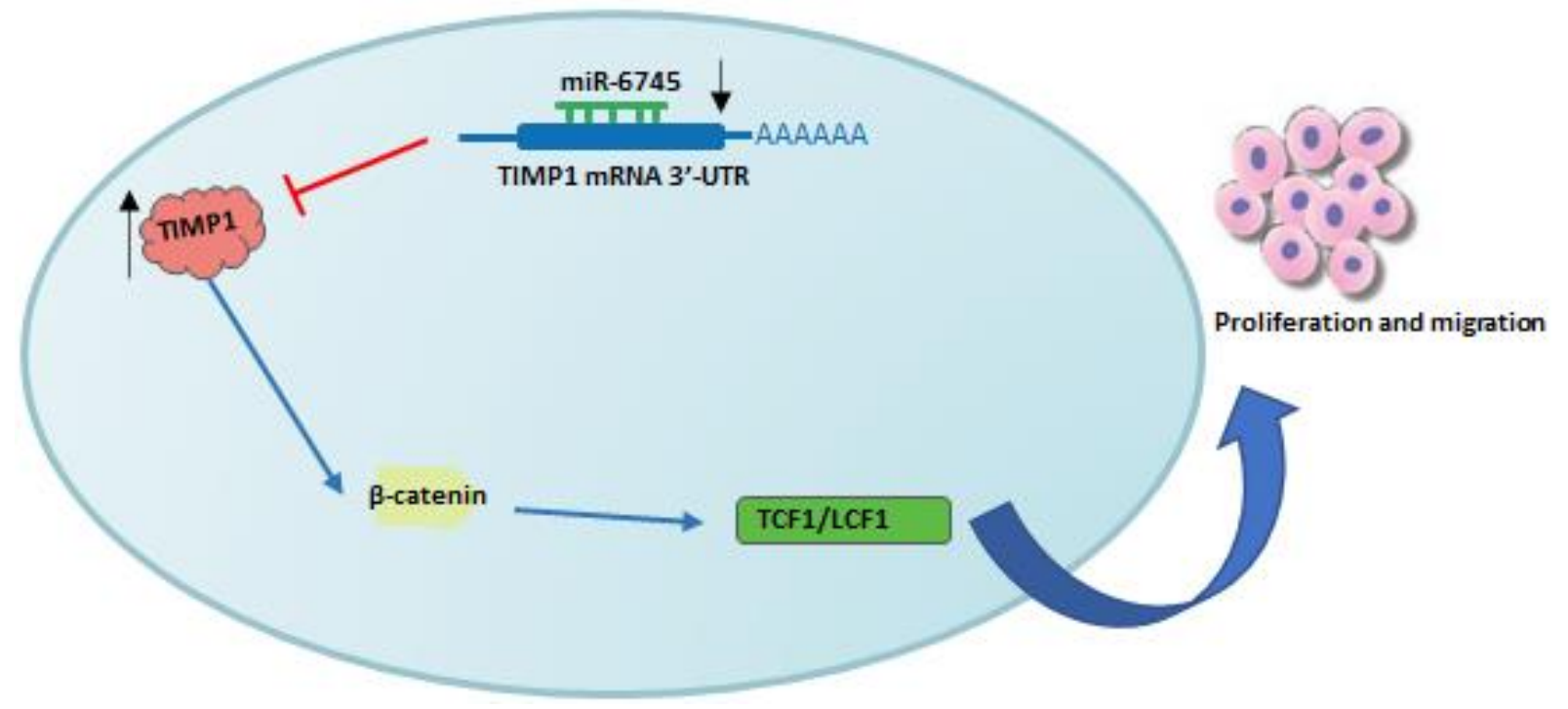

Figure 7. Schematic diagram of roles of miR-6745-TIMP1 axis on Wnt/ $\beta$-catenin signaling and its function in gastric tumorigenesis. Under normal non-transformed conditions, miR-6745 binds to the 3-UTR in the TIMP1 mRNA and down-regulates TIMP1 protein levels. In GC, there is reduced levels of miR-6745 leading to elevated TIMP1 expression and activation of the Wnt/ $\beta$-catenin signaling pathway. 


\section{MATERIALS AND METHODS}

\section{Tissue samples and cell lines}

GC tissue samples and normal gastric tissue samples were collected from the Cancer Hospital of Hubei (Wuhan, P. R. China). This study obtained the informed consent of all patients and the approval of the Ethics Committee of the Cancer Hospital of Hube. MGC-803 and SGC-7901 cell lines were obtained from the Cell Bank of the Chinese Academy of Sciences (Shanghai, China). GC cells were grown in Roswell Park Memorial Institute (RPMI) 1640 medium (DMEM, BI, Israel) supplemented with $10 \%$ FBS and cultured at $37^{\circ} \mathrm{C}$ in a $5 \% \mathrm{CO}_{2}$ humidified incubator.

\section{Transfection}

GC cells were transfected with siRNAs, miRNAs, or plasmids using Lipofectamine 2000 (Invitrogen). miRNA mimics and miR-6745 inhibitor were obtained from RiboBio (Guangzhou, China). siTIMP1 was purchased from GenePharma (Shanghai, China). siRNA-TIMP-1 Target: ATCAACCAGACCACCT TATA; siRNA-Control Target: AATTCTCCGAAC GTGTCACGT. The human TIMP1 overexpression plasmid TIMP1-bio-His was purchased from Addgene (Cambridge, MA).

\section{Real-time RT-PCR}

RNA was extracted using TRIzol reagent (TaKaRa, Japan). 2 ug RNA was reverse-transcribed into cDNA with MLV-reverse transcriptase (Invitrogen), and Hieff qRT-PCR SYBR Green Master Mix was used for qRT-PCR (Tiangen, China). The primer sequences were as follows, TIMP1: 5'-CGCAGCG AGGAGGTTTCTCAT-3' and 5'- GGCAGTGATG TGCAAATTTCC-3'; GAPDH: 5'- ATGACATCAA GAAGGTGGTG -3' and 5'- CATACCAGGAAATGA GCTTG -3'.

\section{Western blotting}

GC cells were lysed by RIPA buffer for $20 \mathrm{~min}$ at $0^{\circ} \mathrm{C}$. The proteins were processed by SDS-PAGE and transferred to PVDF membrane (BioRad). The primary antibodies used in Western blotting were as follows: anti-TIMP1 (ab211926; Abcam), anti- $\beta$ catenin (\#8480; Cell Signaling Technology), antiKi67 (\#9449; Cell Signaling Technology), antiGAPDH (2188, Cell Signaling Technology), anti-p53 (10442-1-AP, Proteintech) and anti-phosphorylated $\beta$ catenin (Ser33/37/Thr41) (\#9561, Cell Signaling Technology).

\section{Cell proliferation assay}

Cell proliferation was detected using MTS Assay Kit (Sigma).

\section{Wound-healing assay}

GC cells were seeded into 6-well plated and scratched with a pipette tip after an overnight incubation. Then, wash off the detached cells with PBS and continue incubating in serum-free medium.

\section{Transwell migration and invasion assays}

Chamber invasion ability were performed with Corning chambers (Corning, USA). $1 \times 10^{5}$ cells cultured with $200 \mu \mathrm{l}$ serum-free media were seeded onto Transwell chambers. After incubating for 24 hours, cells were fixed with $4 \%$ polymethanol for 20 minutes, then stained with $0.1 \%$ crystal violet for 15 minutes, and pictures were taken under an inverted microscope for statistics.

\section{Immunofluorescence}

GC cells were seeded into 12-well plated for 24 hours, and then transfected with siRNAs, miRNAs, or plasmids. After fixation with $4 \%$ paraformaldehyde, the cells were incubated with primary antibody at $4^{\circ} \mathrm{C}$ overnight. After washing 3 times with PBS the next day, the cells were incubated with fluorescently labeled secondary antibodies. A Zeiss confocal microscope was used for photo analysis.

\section{Animal studies}

GC cells were transduced with a lentivirus expressing miR-6745 or a negative control (Genechem, Shanghai, China), and $500 \mathrm{ng} / \mathrm{mL}$ puromycin was used for selection. After 6 days, the cells were verified by realtime RT-PCR.

6-week-old male BALB/c nude mice were obtained from Beijing Vital River (Charles River Laboratories). And $5 \times 10^{7} \mathrm{Lv}-\mathrm{miR}-6745$ or Lv-miR-NC cells in 150 $\mu \mathrm{L}$ PBS were subcutaneously injected into the mice. The mice were euthanized after 28 days. All animal experiments were approved by Institutional Ethics Committee of Wuhan University of Science and Technology (P. R. China).

\section{Statistical analysis}

All data are presented as means \pm SEM. The experimental data were analyzed by SPSS v13.0. The statistical description of the experimental data in each group was represented by $\mathrm{x} \pm \mathrm{S}$. T-test and one way 
ANOVA with Tukey correction was used to analyze the presence of a difference among different groups. $* \mathrm{P}<$ 0.05 . $* * \mathrm{P}<0.01$.

\section{AUTHOR CONTRIBUTIONS}

X.Y.L. conceived and devised the study. X.Y.L., H.L., and Y.X. designed the experiments and analysis. H.L., X.Y.Z., L. and Q.B.Z. performed the experiments and analyzed the data. H.L., and T.C.Z. contributed reagents and materials. X.Y.L., S.Q.F., and H.L. supervised the research and wrote the manuscript. All authors read and approved the final manuscript.

\section{CONFLICTS OF INTEREST}

The authors have no potential conflicts of interest to disclose.

\section{FUNDING}

This work was financially supported by National Natural Science Foundation of China (No. 31501149, 31770815, 31570764) and Hubei Natural Science Foundation (2017CFB537) and Educational Commission of Hubei (B2020001), Hubei Province Health and Family Planning Scientific Research Project (WJ2021Q051, WJ2019M255), Frontier project of applied basic research in Wuhan (2020020601012250), Science and Education Joint Project of Hunan Natural Science and Technology Fund (2020JJ7072).

\section{REFERENCES}

1. Bjerre $C$, Vinther L, Belling $K C$, Würtz $S \varnothing$, Yadav $R$, Lademann U, Rigina O, Do KN, Ditzel HJ, Lykkesfeldt AE, Wang J, Nielsen $\mathrm{HB}$, Brünner $\mathrm{N}$, et al. TIMP1 overexpression mediates resistance of MCF-7 human breast cancer cells to fulvestrant and down-regulates progesterone receptor expression. Tumour Biol. 2013; 34:3839-51.

https://doi.org/10.1007/s13277-013-0969-7 PMID:23881388

2. Xing S, Tian Z, Zheng W, Yang W, Du N, Gu Y, Yin J, Liu $H$, Jia X, Huang D, Liu W, Deng M. Hypoxia downregulated miR-4521 suppresses gastric carcinoma progression through regulation of IGF2 and FOXM1. Mol Cancer. 2021; 20:9.

https://doi.org/10.1186/s12943-020-01295-2

PMID:33407516

3. Togasaki K, Sugimoto $S$, Ohta $Y$, Nanki K, Matano M, Takahashi S, Fujii M, Kanai T, Sato T. Wnt Signaling Shapes the Histologic Variation in Diffuse Gastric Cancer. Gastroenterology. 2021; 160:823-30. https://doi.org/10.1053/i.gastro.2020.10.047 PMID:33217450

4. Jiang T, Xia Y, Lv J, Li B, Li Y, Wang S, Xuan Z, Xie L, Qiu S, He Z, Wang L, Xu Z. A novel protein encoded by circMAPK1 inhibits progression of gastric cancer by suppressing activation of MAPK signaling. Mol Cancer. 2021; 20:66. https://doi.org/10.1186/s12943-021-01358-y PMID:33836754

5. Loe AK, Francis R, Seo J, Du L, Wang Y, Kim JE, Hakim $\mathrm{SW}$, Kim JE, He HH, Guo H, Kim TH. Uncovering the dosage-dependent roles of Arid1a in gastric tumorigenesis for combinatorial drug therapy. J Exp Med. 2021; 218:e20200219.

https://doi.org/10.1084/jem.20200219 PMID:33822841

6. Loyer $X$, Paradis $V$, Hénique $C$, Vion $A C$, Colnot $N$, Guerin CL, Devue C, On S, Scetbun J, Romain M, Paul JL, Rothenberg ME, Marcellin P, et al. Liver microRNA-21 is overexpressed in non-alcoholic steatohepatitis and contributes to the disease in experimental models by inhibiting PPAR $\alpha$ expression. Gut. 2016; 65:1882-94. https://doi.org/10.1136/gutjnl-2014-308883 PMID:26338827

7. Pilon M. The copper microRNAs. New Phytol. 2017; 213:1030-35. https://doi.org/10.1111/nph.14244 PMID:27767213

8. Bushati N, Cohen SM. microRNA functions. Annu Rev Cell Dev Biol. 2007; 23:175-205.

https://doi.org/10.1146/annurev.cellbio.23.090506.12 3406 PMID: 17506695

9. Krol J, Loedige I, Filipowicz W. The widespread regulation of microRNA biogenesis, function and decay. Nat Rev Genet. 2010; 11:597-610. https://doi.org/10.1038/nrg2843 PMID:20661255

10. Song $G$, Xu S, Zhang $H$, Wang $Y$, Xiao $C$, Jiang $T$, Wu L, Zhang $T$, Sun $X$, Zhong L, Zhou C, Wang Z, Peng Z, et al. TIMP1 is a prognostic marker for the progression and metastasis of colon cancer through FAK-PI3K/AKT and MAPK pathway. J Exp Clin Cancer Res. 2016; 35:148.

https://doi.org/10.1186/s13046-016-0427-7 PMID:27644693

11. Akama T, Chun TH. Transcription factor 21 (TCF21) promotes proinflammatory interleukin 6 expression and extracellular matrix remodeling in visceral adipose stem cells. J Biol Chem. 2018; 293:6603-10. https://doi.org/10.1074/jbc.RA117.000456 PMID:29540474

12. Batra J, Robinson J, Soares AS, Fields AP, Radisky DC, Radisky ES. Matrix metalloproteinase-10 (MMP-10) interaction with tissue inhibitors of metalloproteinases 
TIMP-1 and TIMP-2: binding studies and crystal structure. J Biol Chem. 2012; 287:15935-46.

https://doi.org/10.1074/jbc.M112.341156

PMID:22427646

13. Dong J, Ma Q. TIMP1 promotes multi-walled carbon nanotube-induced lung fibrosis by stimulating fibroblast activation and proliferation. Nanotoxicology. 2017; 11:41-51.

https://doi.org/10.1080/17435390.2016.1262919

PMID:27852133

14. Huang R, Wang K, Gao L, Gao W. TIMP1 Is A Potential Key Gene Associated With The Pathogenesis And Prognosis Of Ulcerative Colitis-Associated Colorectal Cancer. Onco Targets Ther. 2019; 12:8895-904. https://doi.org/10.2147/OTT.S222608 PMID:31802901

15. Nalluri S, Ghoshal-Gupta S, Kutiyanawalla A, Gayatri S, Lee BR, Jiwani S, Rojiani AM, Rojiani MV. TIMP-1 Inhibits Apoptosis in Lung Adenocarcinoma Cells via Interaction with Bcl-2. PLoS One. 2015; 10:e0137673.

https://doi.org/10.1371/journal.pone.0137673 PMID:26366732

16. Grunnet $M$, Mau-Sørensen $M$, Brünner N. Tissue inhibitor of metalloproteinase 1 (TIMP-1) as a biomarker in gastric cancer: a review. Scand J Gastroenterol. 2013; 48:899-905. https://doi.org/10.3109/00365521.2013.812235 PMID:23834019

17. Fong KM, Kida Y, Zimmerman PV, Smith PJ. TIMP1 and adverse prognosis in non-small cell lung cancer. Clin Cancer Res. 1996; 2:1369-72.

PMID: $\underline{916309}$

18. Nusse R, Clevers H. Wnt/ $\beta$-Catenin Signaling, Disease, and Emerging Therapeutic Modalities. Cell. 2017; 169:985-99.

https://doi.org/10.1016/i.cell.2017.05.016

PMID:28575679

19. Wang Z, Li B, Zhou L, Yu S, Su Z, Song J, Sun Q, Sha O, Wang $X$, Jiang W, Willert K, Wei L, Carson DA, Lu D. Prodigiosin inhibits $W n t / \beta$-catenin signaling and exerts anticancer activity in breast cancer cells. Proc Natl Acad Sci USA. 2016; 113:13150-55.

https://doi.org/10.1073/pnas.1616336113

PMID:27799526

20. Bugter JM, Fenderico N, Maurice MM. Mutations and mechanisms of WNT pathway tumour suppressors in cancer. Nat Rev Cancer. 2021; 21:5-21.

https://doi.org/10.1038/s41568-020-00307-z

PMID:33097916

21. Wang YY, Li L, Zhao ZS, Wang HJ. Clinical utility of measuring expression levels of KAP1, TIMP1 and STC2 in peripheral blood of patients with gastric cancer. World J Surg Oncol. 2013; 11:81. https://doi.org/10.1186/1477-7819-11-81 PMID:23548070

22. Peng $L$, Yanjiao $M, A i$-guo $W$, Pengtao $G$, Jianhua $L$, Ju $\mathrm{Y}$, Hongsheng $\mathrm{O}$, Xichen $\mathrm{Z}$. A fine balance between CCNL1 and TIMP1 contributes to the development of breast cancer cells. Biochem Biophys Res Commun. 2011; 409:344-49.

https://doi.org/10.1016/i.bbrc.2011.05.021 PMID:21586274

23. Chakrabarti O, Veeraraghavalu K, Tergaonkar V, Liu Y, Androphy EJ, Stanley MA, Krishna S. Human papillomavirus type 16 E6 amino acid 83 variants enhance E6-mediated MAPK signaling and differentially regulate tumorigenesis by notch signaling and oncogenic Ras. J Virol. 2004; 78:5934-45. https://doi.org/10.1128/JVI.78.11.5934-5945.2004 PMID:15140991

24. Sieuwerts AM, Usher PA, Meijer-van Gelder ME, Timmermans M, Martens JW, Brünner N, Klijn JG, Offenberg $\mathrm{H}$, Foekens JA. Concentrations of TIMP1 mRNA splice variants and TIMP-1 protein are differentially associated with prognosis in primary breast cancer. Clin Chem. 2007; 53:1280-88.

https://doi.org/10.1373/clinchem.2006.082800 PMID: 17478562

25. Gao Y, Zhang E, Liu B, Zhou K, He S, Feng L, Wu G, Cao $M$, Wu $H$, Cui $Y$, Zhang $X$, Liu $X$, Wang $Y$, et al. Integrated analysis identified core signal pathways and hypoxic characteristics of human glioblastoma. J Cell Mol Med. 2019; 23:6228-37.

https://doi.org/10.1111/jcmm.14507 PMID:31282108

26. Wills B, Cardona AF, Rojas L, Ruiz-Patiño A, Arrieta O, Reguart N, Carranza H, Vargas C, Otero J, Corrales L, Martín C, Cuello M, Pino LE, et al, and Latin-American Consortium for the Investigation of Lung Cancer (CLICaP). Survival Outcomes According to TIMP1 and EGFR Expression in Heavily Treated Patients with Advanced Non-small Cell Lung Cancer who Received Biweekly Irinotecan Plus Bevacizumab. Anticancer Res. 2017; 37:6429-36.

https://doi.org/10.21873/anticanres.12097 PMID:29061829

27. Makena MR, Ranjan A, Thirumala V, Reddy AP. Cancer stem cells: Road to therapeutic resistance and strategies to overcome resistance. Biochim Biophys Acta Mol Basis Dis. 2020; 1866:165339.

https://doi.org/10.1016/j.bbadis.2018.11.015 PMID:30481586

28. Van den Broeck A, Vankelecom H, Van Delm W, Gremeaux L, Wouters J, Allemeersch J, Govaere O, Roskams T, Topal B. Human pancreatic cancer contains a side population expressing cancer stem cell- 
associated and prognostic genes. PLoS One. 2013; 8:e73968.

https://doi.org/10.1371/journal.pone.0073968

PMID:24069258

29. Danek P, Kardosova M, Janeckova L, Karkoulia E, Vanickova K, Fabisik M, Lozano-Asencio C, Benoukraf T, Tirado-Magallanes $R$, Zhou $Q$, Burocziova $M$, Rahmatova S, Pytlik $R$, et al. $\beta$-Catenin-TCF/LEF signaling promotes steady-state and emergency granulopoiesis via G-CSF receptor upregulation. Blood. 2020; 136:2574-87.

https://doi.org/10.1182/blood.2019004664

PMID:32822472

30. Flanagan DJ, Austin CR, Vincan E, Phesse TJ. Wnt Signalling in Gastrointestinal Epithelial Stem Cells. Genes (Basel). 2018; 9:178.

https://doi.org/10.3390/genes9040178

PMID:29570681

31. Fu X, Zhu X, Qin F, Zhang Y, Lin J, Ding Y, Yang Z, Shang $Y$, Wang L, Zhang Q, Gao Q. Linc00210 drives Wnt/ $\beta$ catenin signaling activation and liver tumor progression through CTNNBIP1-dependent manner. Mol Cancer. 2018; 17:73. https://doi.org/10.1186/s12943-018-0783-3 PMID:29540185

32. Zhan T, Ambrosi G, Wandmacher AM, Rauscher B, Betge J, Rindtorff N, Häussler RS, Hinsenkamp I, Bamberg L, Hessling B, Müller-Decker K, Erdmann G, Burgermeister $\mathrm{E}$, et al. MEK inhibitors activate Wnt signalling and induce stem cell plasticity in colorectal cancer. Nat Commun. 2019; 10:2197. https://doi.org/10.1038/s41467-019-09898-0

PMID:31097693

33. Chakrabarti R, Wei $Y$, Hwang J, Hang X, Andres Blanco M, Choudhury A, Tiede B, Romano RA, DeCoste C, Mercatali L, Ibrahim T, Amadori D, Kannan N, et al. $\triangle$ Np63 promotes stem cell activity in mammary gland development and basal-like breast cancer by enhancing Fzd7 expression and Wnt signalling. Nat Cell Biol. 2014; 16:1004-15.

https://doi.org/10.1038/ncb3040

PMID:25241036

34. Zhang D, Guo S, Wang H, Hu Y. SOX15 exerts antitumor function in glioma by inhibiting cell proliferation and invasion via downregulation of $\mathrm{Wnt} / \beta$-catenin signaling. Life Sci. 2020; 255:117792. https://doi.org/10.1016/j.Ifs.2020.117792 PMID:32416168

35. Wang J, Quan Y, Lv J, Gong S, Dong D. BRD4 promotes glioma cell stemness via enhancing miR-142-5pmediated activation of $\mathrm{Wnt} / \beta$-catenin signaling. Environ Toxicol. 2020; 35:368-76. https://doi.org/10.1002/tox.22873 PMID:31724259

36. Boakye CH, Patel K, Doddapaneni R, Bagde A, Behl G, Chowdhury N, Safe S, Singh M. Ultra-flexible nanocarriers for enhanced topical delivery of a highly lipophilic antioxidative molecule for skin cancer chemoprevention. Colloids Surf B Biointerfaces. 2016; 143:156-67. https://doi.org/10.1016/j.colsurfb.2016.03.036 PMID:27003466 


\section{SUPPLEMENTARY MATERIALS}

\section{Supplementary Figures}

\section{A}
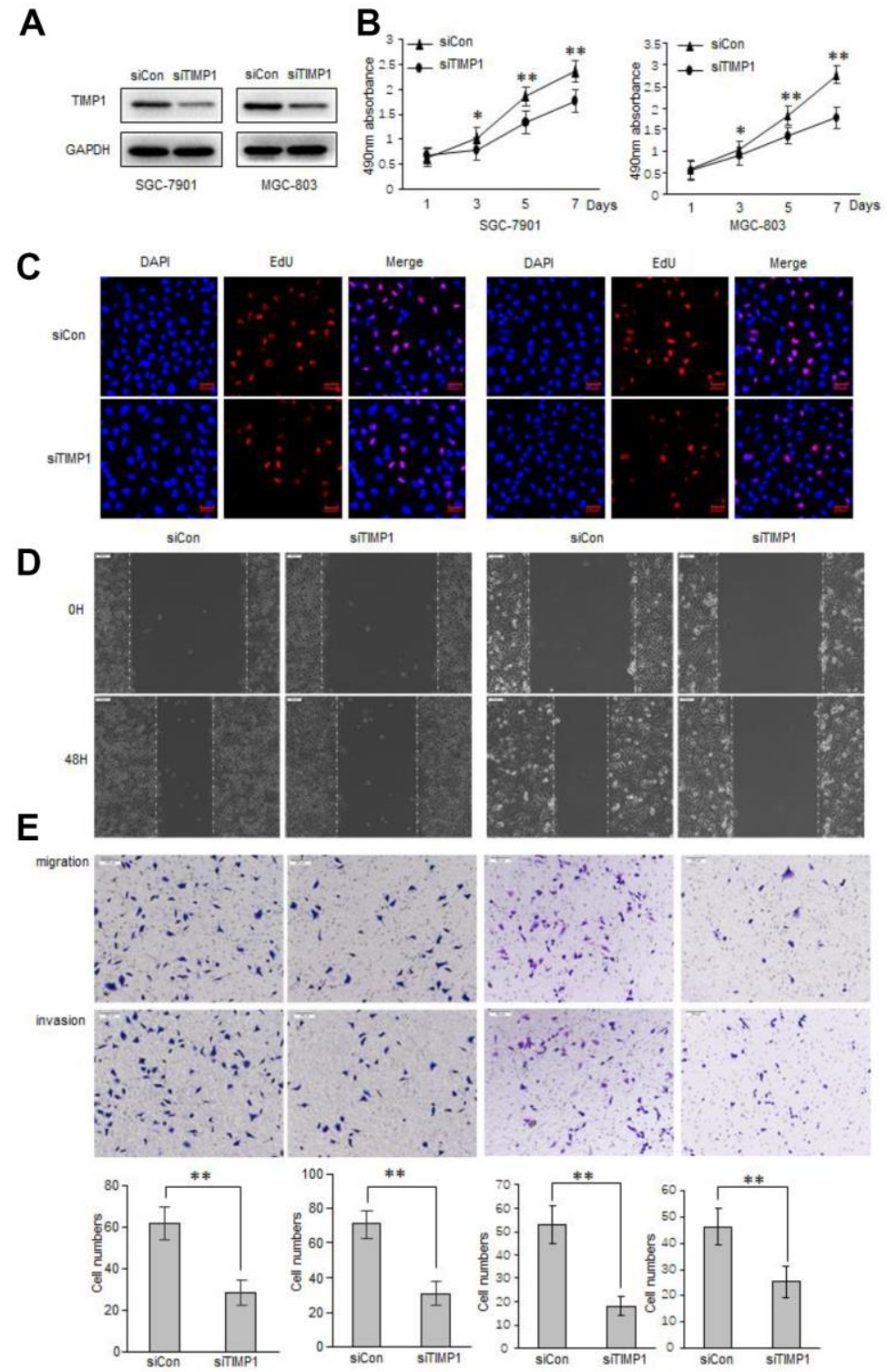

$\mathbf{F}$
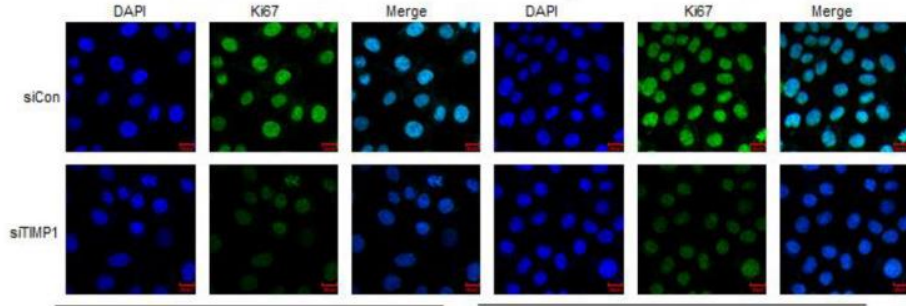

SGC-7901

MGC-803

Supplementary Figure 1. Silencing TIMP1 reduces proliferation, migration, and invasion of GC cells. SGC-7901 and MGC-803 cells were transfected with siTIMP1 or siCon. (A) Levels of TIMP1 were detected by western blot. (B) Cell proliferation was determined by MTS assay. (C) Effect of miR-6745 inhibitor on cell proliferative abilities was examined by EdU incorporation assay. (D, E) Cell metastasis was determined by Scratch wound assays (D) or Transwell migration and Matrigel invasion assays (E). (F) The expression levels of the cell proliferation marker Ki67 were detected by immunofluorescence. Data represent the means $\pm \mathrm{SEM}$. ${ }^{* * P}<0.01$. 


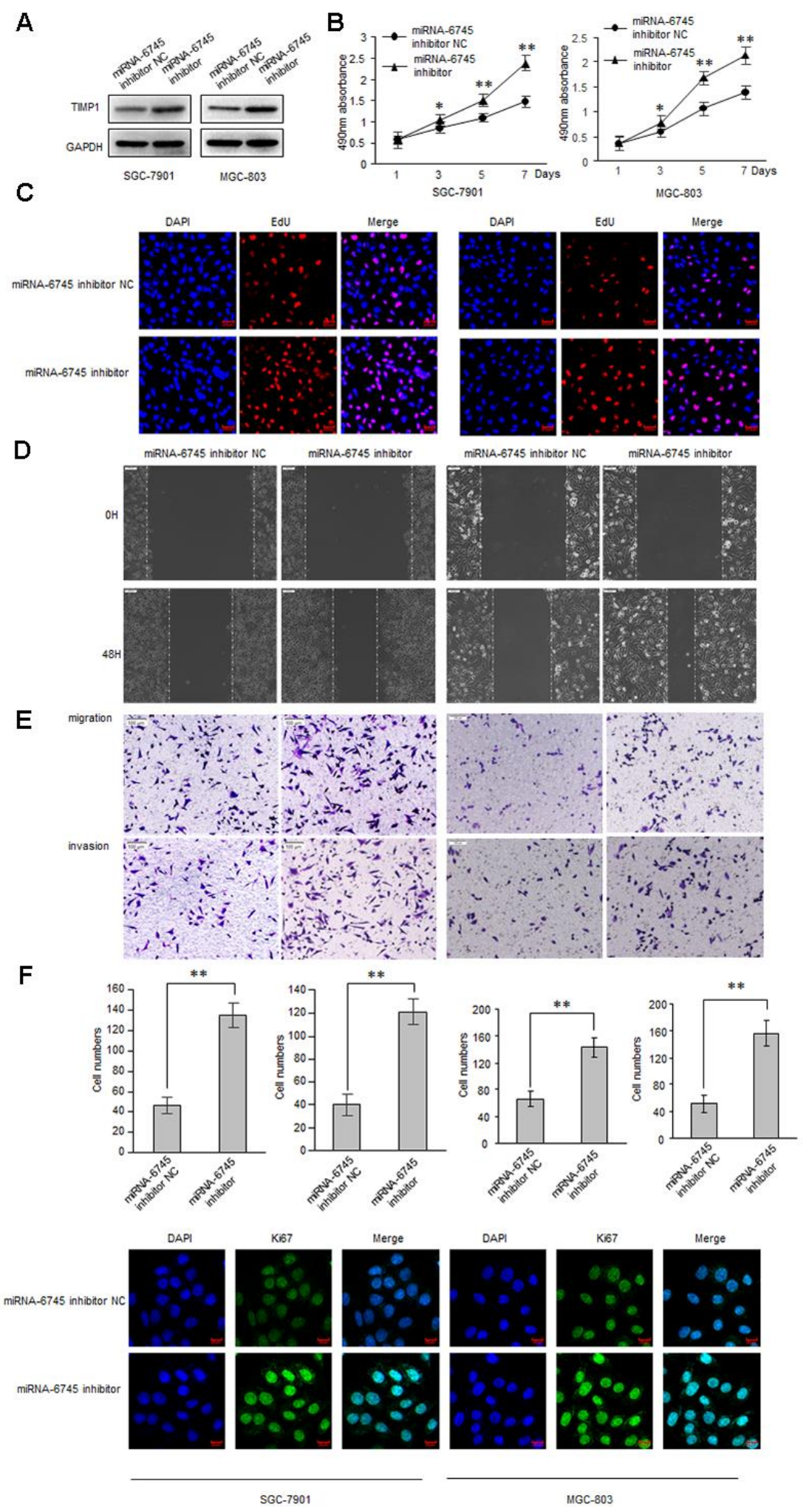

Supplementary Figure 2. miR-6745 inhibitor promotes migratory and invasive ability of GC cells. SGC-7901 and MGC-803 cells were transduced with miRNA-6745 inhibitor NC or miRNA-6745 inhibitor. (A) Levels of TIMP1 were detected by western blot. (B) MTS assay indicted that miRNA-6745 inhibitor promoted ability of proliferation. (C) Effect of miR-6745 inhibitor on cell proliferative abilities was examined by EdU incorporation assay. (D) Cell would healing ability was improved in miRNA-6745 inhibitor cells. (E) Chamber invasion ability was elevated in miRNA-6745 mimics cells. (F) The expression level of Ki67 was enhanced by immunofluorescence. Data represent the means \pm SEM. ${ }^{* * P}<0.01$. 